\title{
The Research Progress of the Influence of Agricultural Activities on Atmospheric Environment in Recent Ten Years: A Review
}

\author{
Pengxiang Ge ${ }^{1}$, Mindong Chen ${ }^{1, * \mathbb{C}}$, Yan Cui ${ }^{1}$ and Dongyang $\mathrm{Nie}^{2}$ \\ 1 Jiangsu Key Laboratory of Atmospheric Environment Monitoring and Pollution Control, Collaborative \\ Innovation Center of Atmospheric Environment and Equipment Technology, School of Environmental \\ Science and Engineering, Nanjing University of Information Science \& Technology, Nanjing 210044, China; \\ gepx@nuist.edu.cn (P.G.); $20201112005 @$ nuist.edu.cn (Y.C.) \\ 2 School of Atmospheric Sciences, Nanjing University, Nanjing 210023, China; dynie@nju.edu.cn \\ * Correspondence: chenmd@nuist.edu.cn; Tel.: +86-255-8731-089
}

Citation: Ge, P.; Chen, M.; Cui, Y.; Nie, D. The Research Progress of the Influence of Agricultural Activities on Atmospheric Environment in Recent Ten Years: A Review. Atmosphere 2021, 12, 635. https://doi.org/10.3390/ atmos12050635

Academic Editor: Maurice Millet

Received: 1 May 2021

Accepted: 11 May 2021

Published: 17 May 2021

Publisher's Note: MDPI stays neutral with regard to jurisdictional claims in published maps and institutional affiliations.

Copyright: (c) 2021 by the authors. Licensee MDPI, Basel, Switzerland. This article is an open access article distributed under the terms and conditions of the Creative Commons Attribution (CC BY) license (https:/ / creativecommons.org/licenses/by/ $4.0 /)$.

\begin{abstract}
In recent years, the industrial emission of air pollution has been reduced via a series of measures. However, with the rapid development of modern agriculture, air pollution caused by agricultural activities is becoming more and more serious. Agricultural activities can generate a large amount of air pollutants, such as ammonia, methane, nitrogen oxides, volatile organic compounds, and persistent organic pollutants, the sources of which mainly include farmland fertilization, livestock breeding, pesticide use, agricultural residue burning, agricultural machinery, and agricultural irrigation. Greenhouse gases emitted by agricultural activities can affect regional climate change, while atmospheric particulates and persistent organic pollutants can even seriously harm the health of surrounding residents. With the increasing threat of agricultural air pollution, more and more relevant studies have been carried out, as well as some recommendations for reducing emissions. The emissions of ammonia and greenhouse gases can be significantly reduced by adopting reasonable fertilization methods, scientific soil management, and advanced manure treatment systems. Regarding pesticide use and agricultural residues burning, emission reduction are more dependent on the restriction and support of government regulations, such as banning certain pesticides, prohibiting open burning of straw, and supporting the recycling and reuse of residues. This review, summarizing the relevant research in the past decade, discusses the current situation, health effects, and emission reduction measures of agricultural air pollutants from different sources, in order to provide some help for follow-up research.
\end{abstract}

Keywords: agricultural activities; greenhouse gases; particulate matter; persistent organic pollutants; health effects; emission reduction measures

\section{Introduction}

Economic development is often accompanied by the sacrifice of the environment. The increasingly serious environmental problems, especially air pollution, have become the focus of the world. The sources of air pollutants include fuel combustion [1,2], industrial emissions [3,4], traffic exhaust [5,6], and agricultural emissions [7,8]. Among them, fuel combustion and industrial emissions have been controlled to a certain extent through a series of measures [9-11]. However, with the rapid development of modern agriculture, the impact of pollutants emitted by agricultural activities on the atmosphere is gradually non-negligible. Agricultural activities emit lots of greenhouse gases (GHGs), such as carbon dioxide $\left(\mathrm{CO}_{2}\right)$, methane $\left(\mathrm{CH}_{4}\right)$ and nitrous oxide $\left(\mathrm{N}_{2} \mathrm{O}\right)$, which account for $10 \sim 12 \%$ of the total GHGs emissions from human activities [12]. $\mathrm{N}_{2} \mathrm{O}$ can stay in the atmosphere for a long time with a higher global warming potential than $\mathrm{CH}_{4}, 298$ times that of $\mathrm{CO}_{2}$. Nearly $40 \%$ of global $\mathrm{N}_{2} \mathrm{O}$ emissions are caused by human activities, including farmland fertilization and fuel burning, with nearly $60 \%$ coming from agricultural activities $[13,14]$. Agricultural 
activities are also the major source of ammonia $\left(\mathrm{NH}_{3}\right)$ [15-18]. Farmland fertilization and animal husbandry can produce vast quantities of $\mathrm{NH}_{3}$. It is estimated that $80 \%$ of $\mathrm{NH}_{3}$ in the global troposphere comes from agricultural emissions [15]. The large amount of $\mathrm{NH}_{3}$ in the atmosphere can react with acid gases to generate secondary aerosols with a high extinction coefficient, which is one of the key factors causing haze pollution [16-18]. In the past few decades, global $\mathrm{NH}_{3}$ emissions have more than doubled, mainly due to the increase of agricultural emissions [19]. In contrast, the contribution of non-agricultural anthropogenic sources is very low [20]. It is estimated that $\mathrm{NH}_{3}$ emissions will increase substantially in the future [21]. In addition, pesticide use and crop residue burning can directly or indirectly produce persistent organic pollutants (POPs), volatile organic compounds (VOCs) and particulate matter (PM), thereby reducing the surrounding air quality and endangering human health $[9,22,23]$. At present, many countries and regions around the world are under the influence of agricultural air pollution [21,22]. Agricultural activities cause 55\% of man-made air pollution in Europe, and they are also responsible for nearly half in eastern China, as well as eastern and western America [21]. In recent years, agricultural air pollution has attracted more and more attention. In order to quantify the contribution of agricultural activities to air pollution, clarify the characteristics and emission factors of pollutants, and formulate effective control measures, a large number of studies have been carried out. This review summarizing the relevant research in the past decade, discusses the current situation, health effects, and emission reduction measures of agricultural air pollutants from different sources, in order to provide some help for follow-up research.

\section{Current Situation of Agricultural Air Pollution}

Similar to earlier studies [24-26], recent studies have pointed out that the sources of agricultural air pollutants were complex, including farmland fertilization [27-30], livestock breeding [31-33], pesticide use [34-37], and agricultural residue burning [38-41]. However, many recent studies found that agricultural machinery also brings a certain amount of air pollution in the entire process of agricultural production [42-45]. What's more, air pollution from agricultural irrigation system cannot be ignored [14,46-48]. There are connections and influences between different sources, which directly or indirectly cause serious harm to the atmospheric environment. In this review, references were selected according to the framework and keywords. As shown in Table 1, numerous studies have been carried out on a global scale, especially in developing countries, through sampling analysis, satellite observation and model simulation in recent years. The results show that agricultural activities can emit PM, VOCs, POPs, GHGs, and other pollutants into the atmosphere through various means. Except livestock breeding and agricultural irrigation, a great deal of studies focused on developing countries, especially China, possibly due to China's vast territory, rapid development of modern agriculture and diverse agricultural production modes. Agricultural emissions in China are somewhat similar to those in other developing countries [34,41], and to the past research results in the United States and some developed countries in Europe [25,29]. 
Table 1. Main pollutants, methods and locations of studies on agricultural air pollution in recent years.

\begin{tabular}{|c|c|c|c|c|}
\hline Sources & Main Pollutants & Methods & Locations & References \\
\hline Farmland fertilization & $\begin{array}{l}\mathrm{NH}_{3} \\
\mathrm{~N}_{2} \mathrm{O}\end{array}$ & $\begin{array}{c}\text { Air sampling } \\
\text { Rain sampling } \\
\text { Satellite observation } \\
\text { Model }\end{array}$ & China, Italy, India, Brazil & {$[13,27-30,49]$} \\
\hline Livestock breeding & $\begin{array}{l}\mathrm{NH}_{3} \\
\text { GHGs } \\
\text { VOCs }\end{array}$ & $\begin{array}{c}\text { Air sampling } \\
\text { Field observation } \\
\text { Model }\end{array}$ & $\begin{array}{l}\text { Switzerland, Canada, } \\
\text { France, Japan, Mexico }\end{array}$ & {$[31-33,50-52]$} \\
\hline Pesticide use & POPs & $\begin{array}{c}\text { Passive air sampling } \\
\text { Soil sampling } \\
\text { Model }\end{array}$ & $\begin{array}{c}\text { China, India, Pakistan, } \\
\text { Nepal, Chile, Argentina, } \\
\text { Australia, Italy }\end{array}$ & {$[34-37,53-57]$} \\
\hline $\begin{array}{l}\text { Agricultural residue } \\
\text { burning }\end{array}$ & $\begin{array}{l}\text { PM } \\
\text { PAHs }\end{array}$ & $\begin{array}{c}\text { Air sampling } \\
\text { Satellite observation } \\
\text { Model }\end{array}$ & $\begin{array}{l}\text { China, Thailand, India, } \\
\text { Mexico, Africa }\end{array}$ & {$[38-41,58-65]$} \\
\hline Agricultural machinery & $\begin{array}{c}\mathrm{NO}_{x} \\
\mathrm{PM}\end{array}$ & $\begin{array}{c}\text { Satellite observation } \\
\text { Model } \\
\text { Water sampling }\end{array}$ & China, Nepal & {$[42-45,66,67]$} \\
\hline $\begin{array}{l}\text { Reservoirs and } \\
\text { agricultural irrigation }\end{array}$ & GHGs & $\begin{array}{l}\text { Sediment sampling } \\
\text { Air sampling } \\
\text { Model }\end{array}$ & China, America, Brazil & {$[14,46-48,68]$} \\
\hline
\end{tabular}

\subsection{Farmland Fertilization}

Agricultural activities are an important source of nitrogen emissions [50]. The use of nitrogen fertilizers in agriculture directly or indirectly emits large amounts of $\mathrm{NH}_{3}$ and $\mathrm{N}_{2} \mathrm{O}[28,30] . \mathrm{NH}_{3}$ emissions vary with the type of fertilizer, depending on nitrogen content, volatility and hydrolysis process [69]. For example, urea, which has a high nitrogen content, emits a high concentration of $\mathrm{NH}_{3}$ and produces nitrous acid (HONO) after fertilized, by contrast, ammonium bicarbonate fertilizer with a lower nitrogen content but higher volatility can cause more emissions [70]. The high concentration of $\mathrm{NH}_{3}$ has subsequent reactions in the atmosphere to generate secondary aerosols such as ammonium sulfate and ammonium nitrate, which can be transported over long distances and cause regional pollution [16-18]. In the late 20th century, global $\mathrm{NH}_{3}$ emissions doubled, $25 \%$ of which came from nitrogen fertilizer application $[21,27]$. According to a report in France, agricultural activities contributed $98 \%$ of $\mathrm{NH}_{3}$ emissions, of which the application of nitrogen fertilizers accounted for $35 \%$. In addition, organic fertilizers such as animal manure also contributed [71]. In southern Italy, high levels of ammonium ions were detected in rainwater, mainly due to the spreading of fertilizers on large areas of farmland during the fertilization periods [28]. Although high $\mathrm{NH}_{3}$ emissions were observed in some developed countries, the contribution of fertilization was small, possibly due to the highly developed animal husbandry in these countries [25]. In China, a traditional agricultural country, agricultural activities contribute $95 \%$ of $\mathrm{NH}_{3}$ emissions [29]. As shown in Figure 1, the map of China shows the spatial distribution of $\mathrm{NH}_{3}$ emissions in China. The hot spots of $\mathrm{NH}_{3}$ emissions mainly appeared in Central China, the Beijing-Tianjin-Hebei region, Jiangsu, and Guangdong, mainly due to large area of arable land, developed planting industry, and high fertilizer application rate in these regions. The maps of the Beijing-Tianjin-Hebei region show the contribution of agricultural and synthetic fertilizer application sources to $\mathrm{NH}_{3}$ emissions in the Beijing-Tianjin-Hebei region. The Beijing-Tianjin-Hebei region is one of the regions with high $\mathrm{NH}_{3}$ emissions in China, and the use of synthetic fertilizers contributed $42 \%$ of $\mathrm{NH}_{3}$ emissions in the Beijing-Tianjin-Hebei region [72]. Moreover, the reasons for the high emissions are similar to other regions, so the Beijing-Tianjin-Hebei region is representative to some extent. In the 1980s, the increase of $\mathrm{NH}_{3}$ emissions slowed down in the United States and other developed countries, mainly because of the reduced use of nitrogen fertilizers and improved fertilizer nitrogen utilization [25]. Soon afterwards, the turning point was also found in China in the late 1990s, mainly owe to stop increasing 
the use of nitrogen fertilizers [29]. Besides, the application of nitrogen fertilizer also causes the emission of $\mathrm{N}_{2} \mathrm{O}[12,13]$, and excessive application may increase the nitrogen load in the surrounding environment through soil and runoff [14]. Bhatia et al. estimated GHG emissions from agricultural soils in India in 2007 [49], and the results showed that nitrogen fertilizer application contributed $69 \%$ of $\mathrm{N}_{2} \mathrm{O}$ emissions. Signor et al. carried out an experiment in a sugarcane field in Brazil [13], and reported that $\mathrm{N}_{2} \mathrm{O}$ emissions were dependent on the amount of nitrogen applied. Furthermore, ammonium nitrate fertilizer enhanced faster $\mathrm{N}_{2} \mathrm{O}$ emissions than urea. Although many related studies have been carried out mostly by model simulations or satellite observations, there is still no very accurate method for measuring emissions from farmland fertilization, mainly due to the volatility of fertilizers and the secondary chemical reaction of $\mathrm{NH}_{3}$.

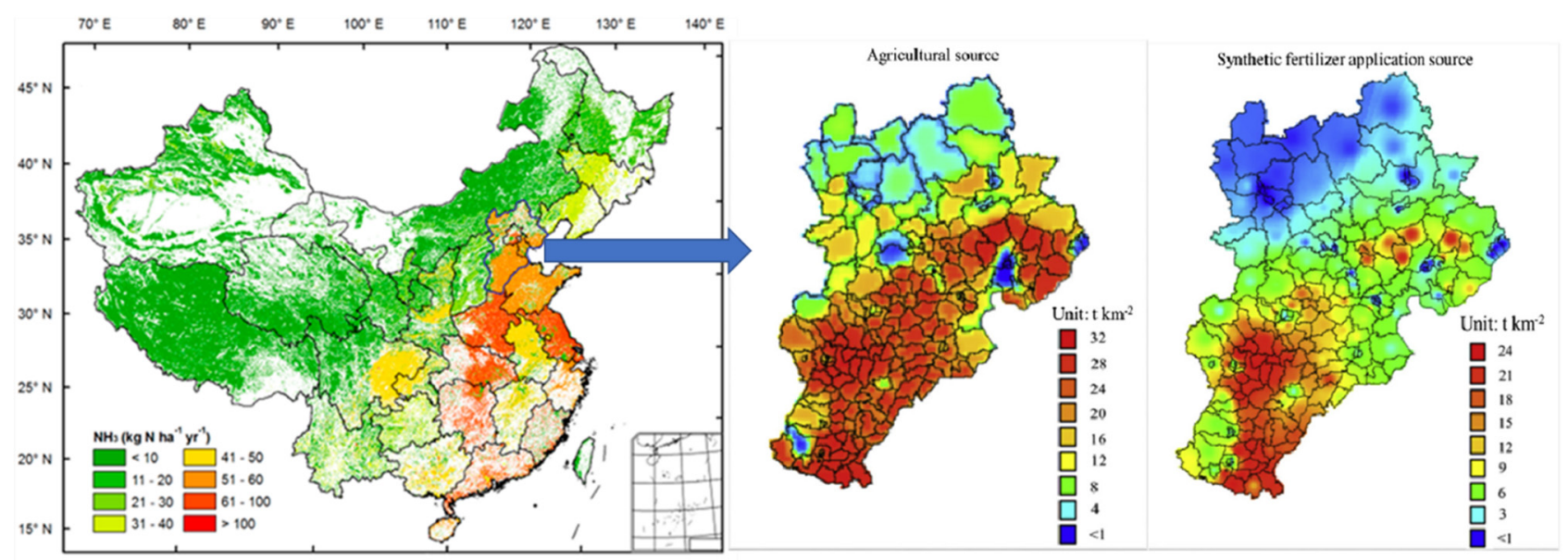

Figure 1. The spatial distribution of $\mathrm{NH}_{3}$ emissions in China [29] and the spatial distribution of agricultural and synthetic fertilizer application sources in the Beijing-Tianjin-Hebei region [72].

\subsection{Livestock Production}

Among agricultural activities, livestock breeding is considered to be one of the largest sources of GHG emissions [52,73]. Livestock breeding practices in different regions are adapted to local conditions. For example, livestock breeding in Japan is usually intensive, which leads to a large amount of pollutants in a narrow area. However, China has a vast land, and livestock breeding generally adopts a combination of free-range and captive breeding, which emits less pollutants per unit area [50]. Beef production is always accompanied by the generation of GHGs, as shown in Figure 2. During cattle feeding, vast quantities of $\mathrm{CH}_{4}$ and $\mathrm{N}_{2} \mathrm{O}$ are released into the atmosphere through enteric fermentation and manure, which is regarded as the major source of GHGs accounting for more than $90 \%$ of the total emissions [32]. The amount of GHGs emitted from enteric fermentation and manure depends on the cattle feed and manure processing system to a great degree. Cattle feed is generally hay, corn, and wheat. Fertilizers and crops also produce GHGs during the growing process of feed ingredients [74]. Cattle manure is also often used as fertilizer, which can produce $\mathrm{CH}_{4}$ and $\mathrm{N}_{2} \mathrm{O}$ under the action of microbes [75]. Moreover, the transport of beef and feed inevitably emits a certain amount GHGs. Lesschen et al. assessed the GHG emissions of different livestock in Europe [31], and confirmed that cattle produced the most GHGs, more than twice as much as pigs. Animal husbandry is also an important source of $\mathrm{NH}_{3}$, accounting for about $40 \%$ of global emissions [33]. Livestock wastes such as manure and compost are major sources of $\mathrm{NH}_{3}$ emissions [50]. Ye et al. established an emission inventory of agricultural ammonia for 2015 in the Beijing-TianjinHebei region by using the WRF-CMAQ model [72], and indicated that livestock breeding was the largest source of $\mathrm{NH}_{3}$ emissions, accounting for $58 \%$ of the total emissions. Among all animals, cattle contributed more. In addition, livestock breeding is also one of the sources of atmospheric particulate matter. $\mathrm{NH}_{3}, \mathrm{NO}_{x}$ and VOCs produced by livestock 
activities are all important precursors for the formation of secondary particulate matter [51] Kammer et al. observed dairy farms and sheep pens at the same time [33], and reported that both buildings emitted a large amount of $\mathrm{NH}_{3}, \mathrm{NO}_{\mathrm{x}}$, and VOCs, mainly from the excretion and respiration of livestock. High concentrations of oxygenated compounds and hydrocarbons, such as ethanol and methanol, were detected in both dairy farms and sheep pens. Acetaldehyde was one of the most abundant VOCs in dairy farms, while nitrogenous compounds such as trimethyl were more significant in sheep pens.

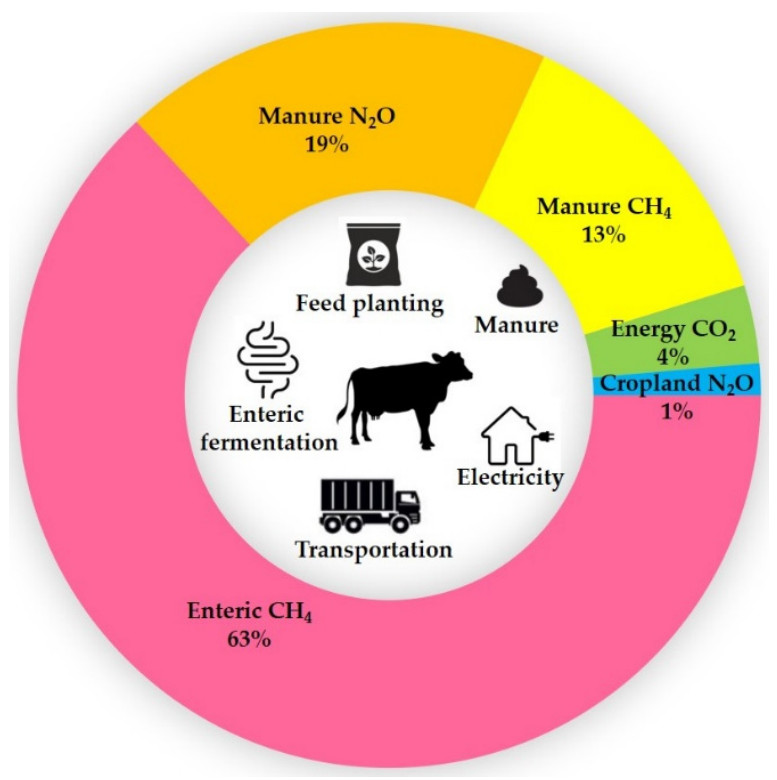

Figure 2. GHG emissions during beef production in Saskatchewan, Canada [32].

\subsection{Pesticide Use}

Pesticides are an important source of persistent organic pollutants, and most of the substances in the internationally recognized POPs list are pesticides [76,77]. After pesticides are sprayed, they either remain in the atmosphere in gaseous form, or are dissolved in water vapor, or adsorbed on solid particles. The pesticides decompose into various difficultto-degrade toxic substances in the atmosphere, which can migrate for a long distance and cause regional pollution [78]. As shown in Figure 3, POPs in the atmosphere can subside to land and aquatic ecosystems, accumulate in crops and animals, and be exposed to human through the food chain, then causing adverse health effects $[55,79]$. Compared with developed countries, higher concentrations of POPs are generally observed in developing countries [35]. Although many pesticides have been banned, they are still widely used in many areas to kill pests and deal with infectious diseases [37]. Syed et al. evaluated the presence of organochlorine pesticides (OCPs) in the atmosphere of Punjab, Pakistan [34]. The concentration of DDTs in the atmosphere of the study area was much lower than that in the coastal areas of the United States, and comparable to that in the southern United States and the Taihu Lake Basin of China. Pegoraro et al. analyzed the atmospheric POPs in different areas of Cordoba, Argentina, and observed higher concentrations of endosulfan and heptachlor in agricultural areas [37]. Nasir et al. conducted sampling and analysis in industrial and agricultural areas of Pakistan [35], and the results showed that the concentrations of endosulfan, DDTs, lindane, PCBs, and heptachlor in agricultural areas were higher than those in industrial areas, mainly due to their continuous use in agriculture. Because of the long-distance migration and non-degradability of POPs, agricultural waste would enter the Arabian Sea through rivers, which may cause regional or even global pollution. Pesticide deposits in the ocean can also volatilize and reenter the atmosphere to cause secondary pollution. Similarly, crop residues such as straws in farmland can also cause secondary pollution of pesticides. Straw returning can not only reduce the pollution of straw burning, but also help maintain soil fertility. According to the surveys, $70 \%$ of corn 
stalks are put back into farmland in northern China [80], while $70 \%$ of rice stalks are left in farmland in Japan [81]. Due to the persistence and bioaccumulation of POPs, pollutants can migrate into the atmosphere and soil through the surface of crops, and pesticides in the soil can also enter the atmosphere again through volatilization. Wang et al. predicted the fate of endosulfan in the atmosphere with the EUSES model [36], and the study indicated that $54.7-70.3 \%$ of endosulfan entered the atmosphere by indirect means, such as crop surface volatilization and straw returning.

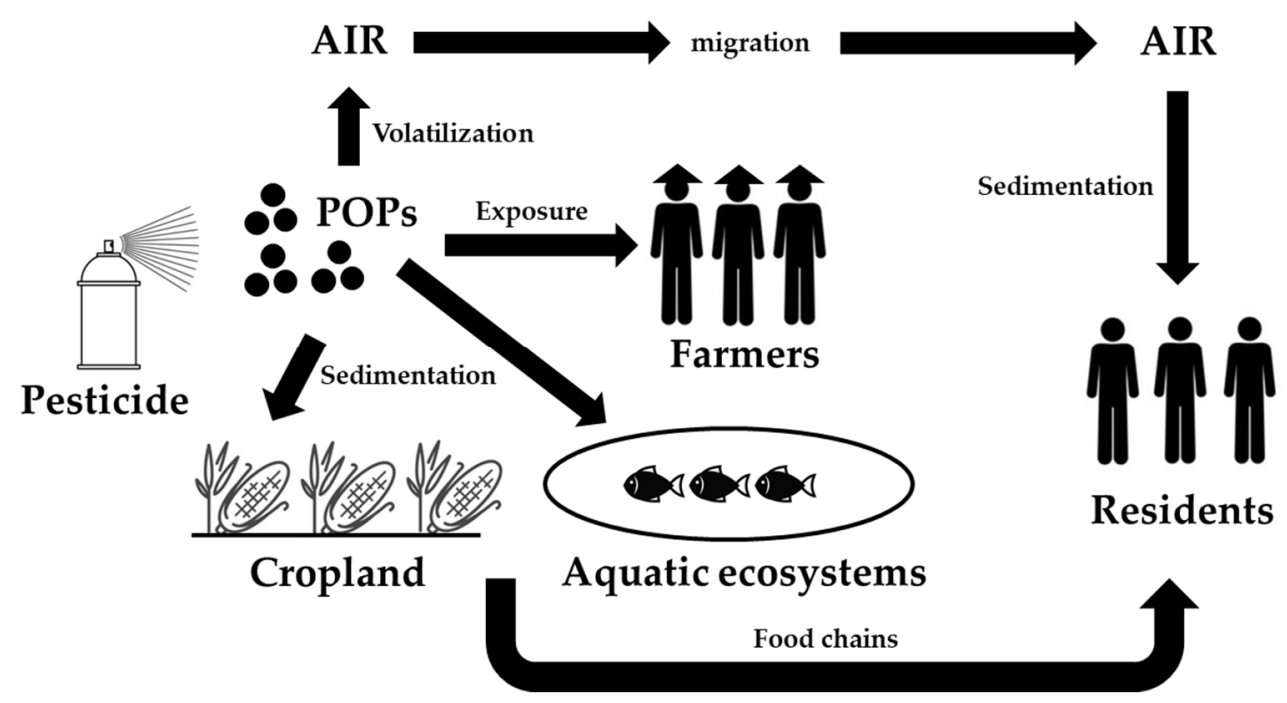

Figure 3. Pesticides can influence the environment and human health in different ways.

\subsection{Agricultural Residue Burning}

The burning of crop residues is a common agricultural practice, especially in developing countries, because it is a simple and economical method of removing residues [82,83]. However, this practice involves an inefficient combustion process. The open incomplete burning of crop residues releases large amounts of particulate matter and organic pollutants into the atmosphere, which adversely affect the regional atmospheric environment and climate change, and harm the health of surrounding residents [58,84,85]. Chang et al. assessed the open biomass burning in tropical Asia [62], and clarified that agricultural residue burning was the second largest source of pollutants after forest fires. Moreover, satellite observations may miss small fires, so agricultural burning may be underestimated. Agapol et al. used remote sensing technology to observe the $\mathrm{PM}_{2.5}$ emissions from the open burning of rice residues in Thailand [40], and found peaks in the central and northern regions. The burning of corn residues was the main source of $\mathrm{PM}_{2.5}$. In the source analysis of PAHs in northern Thailand [39], Siwatt et al. pointed out that agricultural residue burning contributed $22.5 \%$ of the total emissions, second only to road mobile sources, and the major emission was benzopyrene. Niveta et al. indicated that the atmospheric pollutants produced by the burning of crop residues in different regions of India varied greatly, mainly depending on the type of crop and combustion efficiency [65]. In general, agricultural residue burning emits more high-molecular-weight PAHs, of which $4 \sim 6$ ring PAHs account for more than 95\% [38]. China is also a large agricultural country with open straw burning accounting for more than $44 \%$ of the total straw burning in Asia [41]. Agricultural residues are often used for kitchen firewood or heating, so crop residue burning is an important source of carbonaceous aerosols in China [86]. In the past 30 years, black carbon emissions from farmland combustion in China have increased by 25 times [64], with open burning of crop residues in Shandong being the largest contributor [63]. Similar to the result of the Indian study $[38,65]$, there were significant differences in emissions from different types of biomass burning in different regions of China [87]. Crop straw burning was the main source in Northeast Plain and North China Plain, while household firewood burning was the key emission source in Sichuan Basin. In terms of crop types, corn, rice and wheat 
straw burning provided the highest emissions, accounting for $80 \%$ of the total emissions from straw burning [41]. Based on emission data for the past decade, although the total anthropogenic $\mathrm{PM}_{2.5}$ emissions showed a slight downward trend [88,89], the $\mathrm{PM}_{2.5}$ emissions from biomass burning increased slowly (Figure 4a), which means that biomass burning was providing an increasing contribution. What's more, high emissions from agricultural burning in China were shifting from Sichuan Plain to North China Plain and Northeast Plain (Figure 4b), as a result of large farmland areas and abundant agricultural activities in these regions. Besides, it was also associated with large-scale changes in land use [90].
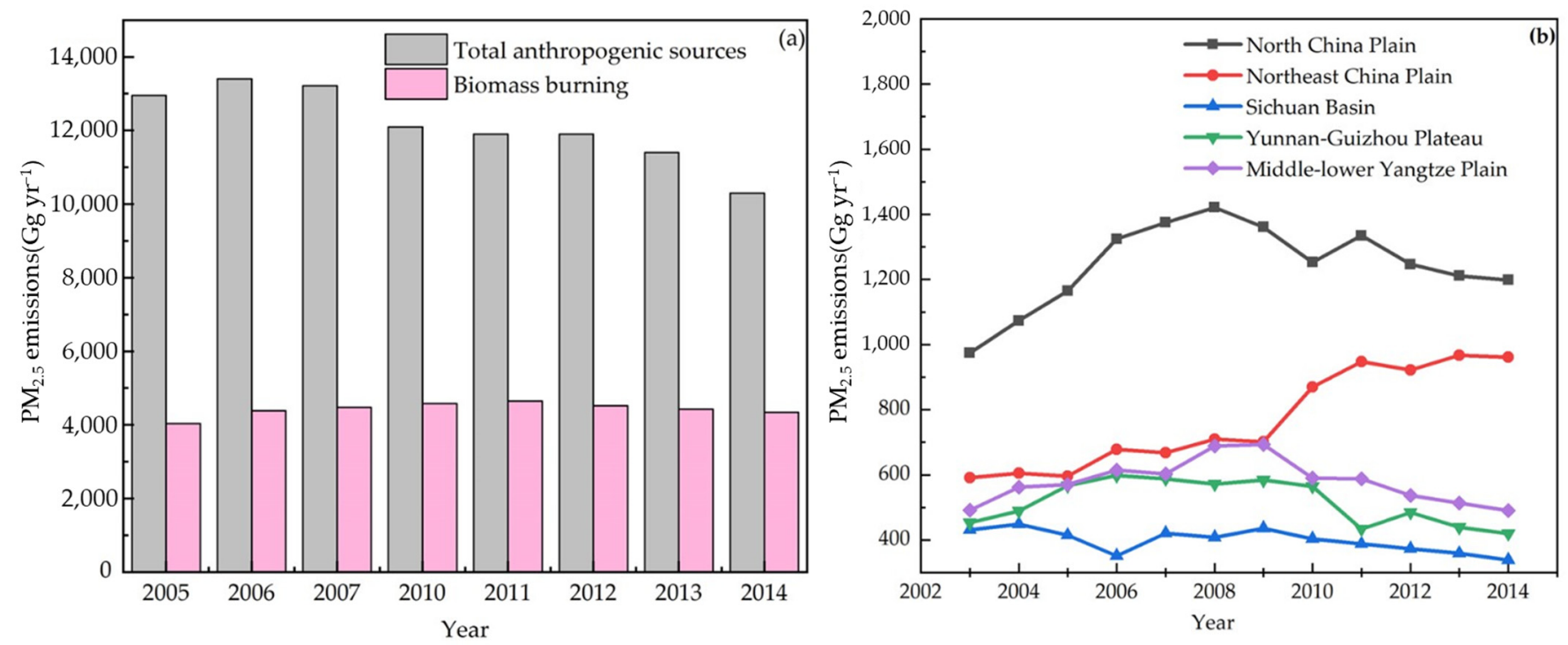

Figure 4. (a) Annual $\mathrm{PM}_{2.5}$ emissions from total anthropogenic sources and biomass burning in some years in China and (b) annual $\mathrm{PM}_{2.5}$ emissions from biomass burning in different regions of China [41].

\subsection{Agricultural Machinery}

With the development of modern agriculture, the application of agricultural machinery is more and more extensive. Agricultural mechanization promotes agricultural economy, but also brings environmental pollution [43,91]. Agricultural machinery is a typical nonroad mobile source, with diesel as the main fuel, which emits $\mathrm{NO}_{x}$, hydrocarbons, sulfur dioxide $\left(\mathrm{SO}_{2}\right), \mathrm{CO}_{2}$, carbon monoxide $(\mathrm{CO})$ and atmospheric particulate matter $[44,50,67]$. Wang et al. established an emission inventory of non-road sources in China [66] and pointed out that agricultural machinery was the primary emission source, and the level of pollutants was related to the quality of fuel. Guo et al. estimated the emissions from non-road mobile sources for 2015 in the Beijing-Tianjin-Hebei region of China [44]. The emissions of agricultural machinery were higher than those of construction machinery, accounting for $60 \%$ to $71 \%$ of the total emissions. Zhang et al. estimated the emissions of agricultural machinery in the Yangtze River Delta region of China through satellite observations [45], and observed the largest emissions in central and northern Anhui and Jiangsu. Figure 5 shows the ratio of agricultural machinery emissions to road vehicle emissions during busy season. The red and orange parts indicate that agricultural machinery emissions are higher than road vehicle emissions, while the green parts are the opposite. During the busy season of agricultural activities, the pollutant emissions from agricultural machinery were comparable to or even higher than those from road vehicles. Nevertheless, it is a challenge to accurately distinguish between agricultural vehicles and road vehicles. Lang et al. developed a higher-resolution emission inventory of agricultural machinery in China [42]. There were high emissions in northeast, northern and central regions of China, which mainly occurred in late April, mid-June, and early October. Pollutant levels were significantly correlated with the area of cultivated land and grain production. Compared with road mobile sources, agricultural machinery emitted $72 \%$ of $\mathrm{PM}_{10}, 83 \%$ of $\mathrm{PM}_{2.5}, 36 \%$ 
of hydrocarbons, and $35 \%$ of $\mathrm{NO}_{\mathrm{x}}$, respectively, indicating that the air pollutants emitted by agricultural machinery cannot be ignored. Several studies [42-44,92] consistently suggested that tractors and agricultural vehicles contributed the most to pollutants emissions. In China, tractors accounted for more than half of the total emissions from agricultural machinery, while agricultural vehicles contributed $82 \%$ of hydrocarbon emissions. In addition, planting machinery also had considerable emissions, which was also the focus of emission control. Although agricultural mechanization is very developed in many countries around the world, there are few related studies in other countries and regions, so more research on air pollutants from agricultural machinery can be carried out in the future.

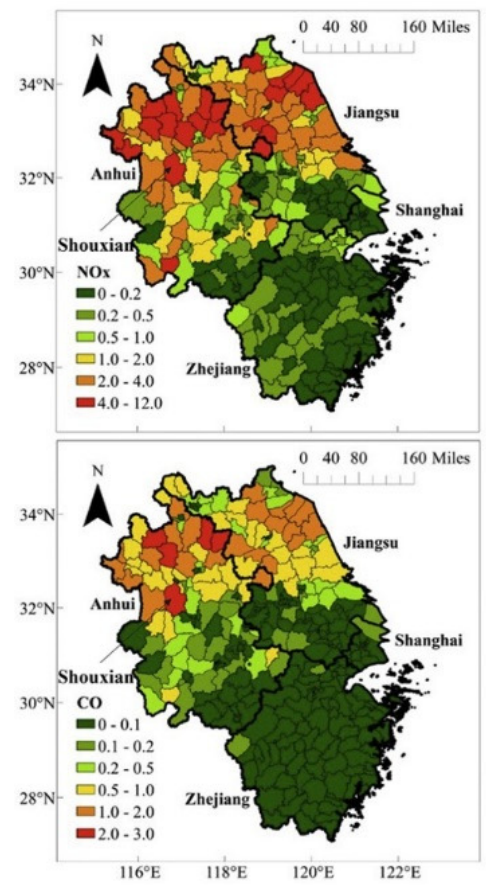

(a) Spring

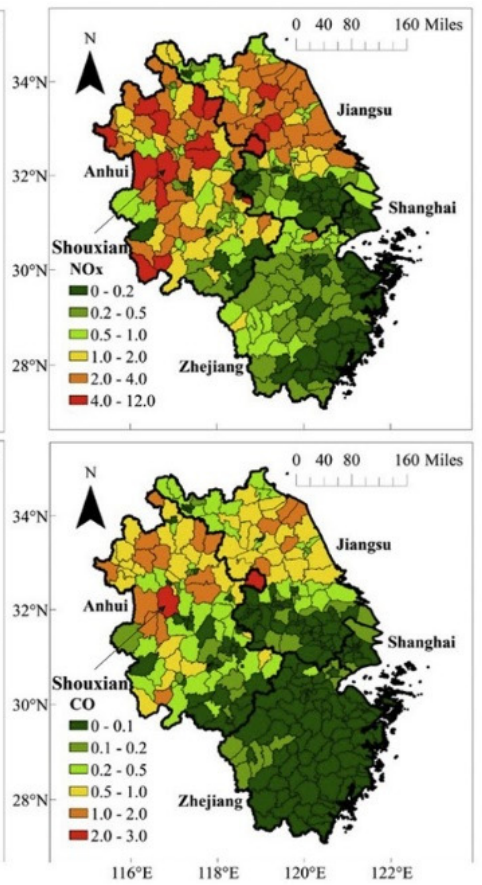

(b) Autumn

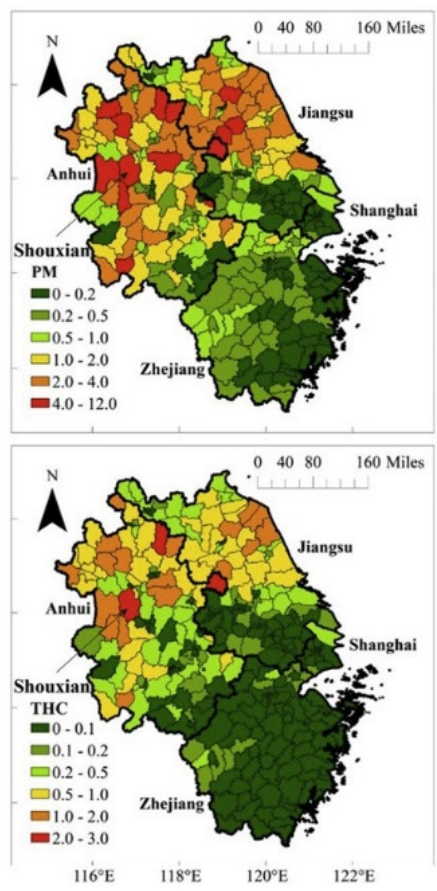

$116^{\circ} \mathrm{E} \quad 118^{\circ} \mathrm{E} \quad 120^{\circ} \mathrm{E} \quad 122^{\circ} \mathrm{E}$

Figure 5. Ratio of emissions from agricultural machinery and road vehicles during busy season (a) Spring and (b) Autumn in the Yangtze River Delta of China [45].

\subsection{Reservoirs and Agricultural Irrigation}

The construction of reservoirs has solved the problem of drinking water and farmland irrigation in rural areas, which is of great significance to agricultural development [93-95]. Oxygen-containing sediments with abundant microorganisms in aquatic ecosystems can produce $\mathrm{CO}_{2}$ through respiration, and also $\mathrm{CH}_{4}$ under hypoxic conditions. In the presence of dissolved oxygen, $\mathrm{CH}_{4}$ can be oxidized to $\mathrm{CO}_{2}$ by microorganisms. Hofmann suggested that shallow-water zones were the high emission source of $\mathrm{CH}_{4}$ [46]. Because $\mathrm{CH}_{4}$ had a short residence time with a low oxidation efficiency in shallow waters of lakes and reservoirs, it would not be oxidized into $\mathrm{CO}_{2}$ and directly discharged into the atmosphere. Beaulieu et al. performed sampling and observation in the Harsha Lake Reservoir of the United States [47] and found higher $\mathrm{CH}_{4}$ emissions in the upper reaches of the reservoir, mainly due to more sediments in the upper reaches. Moreover, the results showed that the $\mathrm{CH}_{4}$ emissions of reservoirs were much higher than that of open waters, indicating that reservoirs were not a negligible $\mathrm{CH}_{4}$ emission source. In addition, nitrogen fertilizer applied to farmland can enter the agricultural irrigation watersheds through leaching and runoff, resulting in an increase of the nitrogen load in the aquatic environment, and the release of $\mathrm{N}_{2} \mathrm{O}$ into the atmosphere by nitrification and denitrification [14,48]. Cao et al. found in the experiment of vegetable greenhouses that excessive fertilization and irrigation were the main causes of $\mathrm{N}_{2} \mathrm{O}$ emissions, and that $\mathrm{N}_{2} \mathrm{O}$ emissions were significantly correlated 
with soil water content [48]. Wu et al. carried out floating chamber observations in agricultural irrigation watersheds of southeastern China [14], and confirmed that the high $\mathrm{N}_{2} \mathrm{O}$ emissions occurred mostly during crop growth, accompanied by agricultural irrigation, drainage or heavy rainfall, which may be influenced by agricultural practices and a monsoon climate. In general, $\mathrm{N}_{2} \mathrm{O}$ fluxes are higher at night than daytime $[68,96]$. Agricultural activities in the daytime usually introduce plenty of sewage and nitrogenous nutrients into the water, creating an environment with low oxygen and rich nitrate nitrogen, which promotes denitrification and $\mathrm{N}_{2} \mathrm{O}$ production. Wu et al. also calculated the $\mathrm{N}_{2} \mathrm{O}$ emissions with a model [14]. The calculated diel variation was approximate to the result of the floating chamber observation, but the seasonal variation data were significantly lower than the observation data, probably due to the uncertainty of emission factors.

\section{Health Effects of Agricultural Air Pollutants}

Agricultural activities emit a great deal of air pollutants via multiple pathways, which reduces the surrounding air quality, affects regional climate change, and most importantly, threatens the health of surrounding residents. Globally in 2010, agricultural activities resulted in $20 \%$ of premature deaths relevant with air pollution [22]. In some countries of Europe and East Asia, this proportion was even close to 50\%. For example, agricultural air pollution accounted for $43 \%, 52 \%, 45 \%$, and $38 \%$ of premature deaths in Russia, Ukraine, Germany and Japan, respectively [22]. Agricultural activities are inseparable from the use of pesticides. POPs are brought into the atmosphere after pesticides spraying, transferred through sedimentation and food chains, and finally ingested by human beings via mouth, nose and skin, which causes harmful effects on the human health. Niu et al. explained that the intake of contaminated food was the primary route for people to be affected by pesticides, which may pose a greater threat to human health over time [97]. Wang et al. disclosed that exposure to POPs unbalanced the human immune system and adversely influenced human development [56]. Cortes et al. performed a risk assessment of pesticide inhalation exposure in central Chile [54] and revealed that children aged 1-6 were most sensitive, implying the genetic toxicity of pesticides. In addition, long-term exposure to pesticides could increase the probability of malformation, cognitive impairment and cancer in the offspring of agricultural workers, as well as increase workers' anxiety and harm their mental health [98]. Agricultural residue burning produces a mass of particulate matter and noxious gases, of which organic components are the most toxic. Niu et al. ascertained that PAHs from incomplete combustion could obviously cause cell damage and inflammation [99]. Tong et al. established a high negative correlation between cell viability and organic components in particulate matter by a series of experiments [100]. Melki et al. explained that exposure to particulate matter would lead to genetic mutations, extremely owing to organic components [101]. The results of many cytotoxicity experiments [102-104] also showed that exposure to atmospheric particles would result in reduced cell viability, oxidative stress and DNA damage, among which organic components, especially PAHs, played a key role. Farmland fertilization and animal husbandry produce vast quantities of nitrogen-containing gases, which can form secondary atmospheric particles such as ammonium aerosols and nitrate aerosols in the atmosphere. These particles are highly hydrophilic, in which ammonium ions, sulfate ions and nitrate ions constitute $50 \%$ to $80 \%$ of the water-soluble components. Most water-soluble ions themselves have no toxicity, however, they can flow through the human body with the blood after entering and bring about adverse health effects. Lin et al. conducted a study on the relationship between particulate matter and stroke mortality in Guangzhou [105], and determined that ammoniums, nitrates, and sulfates in particulate matter were significantly correlated with stroke mortality. Qiao et al. identified that sulfates and ammoniums played important roles when exposure to particulate matter affected the weight of newborns [106]. $\mathrm{NO}_{x}$ and VOCs emitted by agricultural activities are precursors of tropospheric photochemical reactions, which can generate ozone and more harmful secondary organic aerosols [23], thus increasing the incidence of respiratory diseases [107]. 
Nitric oxide and nitrous oxide can also destroy the stratospheric ozone layer, potentially contributing to diseases such as skin cancer and cataract [108].

\section{Emission Reduction Measures}

In addition to environmental pollution and health hazards, agricultural emissions also impose a certain economic burden. In order to meet the emission requirements of the Kyoto Protocol, agricultural income of Spain for 2020 was expected to fall by $5.9 \%$ because of the contracted agricultural activities [109]. In China, health damage cost caused by nitrogen emissions for 2008 was more than 20 billion dollars, about $0.5 \%$ of gross domestic product, and the cost by agricultural emissions accounted for more than $50 \%$ of the total cost [29]. Therefore, it is necessary to propose and implement emission reduction measures (Table 2) for sustainable development as soon as possible. The authors propose these mitigation measures based on references, relevant government policies, and their own understanding. Most of the proposals are supported by references or case studies.

Table 2. Summary of emission reduction methods.

\begin{tabular}{|c|c|c|}
\hline Sources & Abatement Options & Description \\
\hline \multirow{2}{*}{ Agricultural residue burning } & Government regulations & Extending the no-burning period \\
\hline & Recycling of residues & Processing into feed, ethanol and fuel \\
\hline \multirow[t]{2}{*}{ Pesticide use } & Government regulations & $\begin{array}{c}\text { Prohibition or restriction specific pesticides } \\
\text { Producing better alternatives }\end{array}$ \\
\hline & & $\begin{array}{l}\text { Producing better alternatives } \\
\text { Using low-emission fertilizers }\end{array}$ \\
\hline \multirow{3}{*}{ Farmland fertilization } & Scientific fertilization & Fertilization in small doses and multiple times \\
\hline & & Deep fertilization \\
\hline & Farmland management & $\begin{array}{l}\text { Adjusting the } \mathrm{pH} \text { of soil } \\
\text { Adding microorganisms }\end{array}$ \\
\hline \multirow{2}{*}{ Livestock breeding } & Manure management & Advanced manure treatment systems \\
\hline & Feed management & $\begin{array}{l}\text { Low-fiber feed and additives } \\
\text { Using high-quality fuels }\end{array}$ \\
\hline \multirow[t]{2}{*}{ Agricultural machinery } & Lower-emission options & Lower-emission machinery \\
\hline & & Modifying engines \\
\hline \multirow{3}{*}{ Reservoirs } & Sediment management & Reinforcing the embankment \\
\hline & seament management & Cleaning the sediments \\
\hline & Water management & Adjusting the size of the reservoir \\
\hline
\end{tabular}

Agricultural residue burning is relatively easier to be controlled by government laws and regulations, for instance, extending the no-burning period and recycling of residues. According to estimates [60], removing farmland burning of the Shandong Peninsula region could reduce $40 \%$ of organic carbon emissions of the Bohai Rim region in summer, mainly through the recycling and utilization of residues. For example, besides providing nutrients by returned to the field, corn stalks also have many commercial values, such as feed processing, ethanol preparation, and usage as fuel for power plants [41]. Yet government support and scientific guidance are required in the early stage. As mentioned above, agricultural residues may contain pesticide residues, which may cause secondary pollution if they are directly put back into farmland, so screening is required. In addition, the use of corn stalks to produce ethanol requires mature technology and certain cost, so it requires scientific guidance, as well as support of government policies and subsidies. Similarly, the use of pesticides can also be controlled by government laws. The Stockholm Convention recognized certain pesticides as POPs and required their prohibition or restriction. In China, 89 pesticides are banned or restricted according to the Regulations on Pesticide Management, and users must strictly follow the requirements to use pesticides, otherwise they will be punished. At the same time, the government can order pesticide manufacturers to produce new pesticides with lower doses and higher efficacy, and educate pesticide users to prevent them from using more dangerous alternatives without permission. 
Farmland fertilization produces large amounts of $\mathrm{NH}_{3}$ and $\mathrm{N}_{2} \mathrm{O}$. The control of fertilization and farmland management can achieve positive effects on emission reduction. Firstly, give priority to the use of low-emission fertilizers, as organic fertilizers usually have much lower emissions than synthetic fertilizers [13]. It is more scientific to apply fertilizers in small doses and multiple times, which can improve fertilizer efficiency and generate lower emissions compared with large-dosage fertilization in one go [12]. Fertilizers should be buried deep in the soil to increase the residence time of the fertilizer in the soil and improve the effect of fertilization [110]. In addition, we can manage farmland soil by adjusting the $\mathrm{pH}$ of soil, adding microorganisms and other methods, and utilize soil to consume pollutants generated by fertilizers. Livestock breeding is also an important source of $\mathrm{NH}_{3}, \mathrm{~N}_{2} \mathrm{O}$, and $\mathrm{CH}_{4}$ emissions. A study in northern China [111] indicated that improved livestock manure treatment systems could decrease $\mathrm{NH}_{3}$ emissions by $40 \%$, thereby reducing the emissions of nitrogen-containing aerosols. Livestock manure can be intensively composted, buried deep, or stored in solids. Intensive compost produces the most GHGs, while solid storage emits the least [32]. Livestock manure can also be utilized in biogas digesters to take advantage of the discharged $\mathrm{CH}_{4}$, which can both reduce pollutant emissions and produce energy. GHGs emitted by livestock principally come from enteric fermentation and manure, so feed management also matters aside from manure management. The use of low-fiber feed and additives can effectively reduce the GHGs produced enteric fermentation and manure [32], but this measure increases the cost and may have adverse health effects on cattle.

For agricultural machinery, pollutant emissions can be reduced by using high-quality and environmentally friendly fuels, but this means higher costs. In addition, users can also choose lower-emission machinery or modified engines. The emission reduction measures for reservoirs can be formulated according to the mechanism of GHGs generation. Reinforcing the embankment to prevent sediments from flowing into the water area and regularly cleaning the sediments in the water can reduce the generation of GHGs. By adjusting the size of the reservoir to reduce the surface area and increase the depth of the water area, the GHGs emission can be reduced as well. However, these measures require a lot of manpower and cost, so better mitigation measures are needed in the future.

\section{Outlooks}

This review summarizing the research progress in the past decade, discusses the current situation, health hazards and emission reduction measures of agricultural air pollutants from different sources. With the growing world population, the demand for food will further increase. Agricultural activities will constantly emit more air pollutants in the absence of better mitigation measures. Therefore, it is necessary to carry out more studies on agricultural air pollution. Current studies are mostly focused on the sources and identification of agricultural pollutants, but still relatively weak in the environmental and health effects. In terms of research methods, sampling analysis and model simulation are the most common. Sampling analysis is often adopted in the study of emissions from agricultural residue burning and pesticide use. In particular, passive air sampling is commonly used for the collection of POPs, mainly because this method is simple and economical. The research on emissions from animal husbandry is often performed through field observation or model simulation. As an emerging method, model is also widely used for other research. However, due to the complex reaction mechanisms and synergistic effects of multiple factors in actual emissions, there are gaps between the results of model simulation and actual observation, which need to be quantified by a large amount of research data and narrowed via optimizing models. For field observation experiments, multiple observations at multiple sites can be performed to determine the uncertainties of pollutant emissions. In addition, there is still some work that can be carried out in the future. For example, the better feed formula to reduce GHGs emissions from the livestock production can be studied. Emission inventories of agricultural machinery can be established in other regions than China with developed agricultural mechanization. 
Besides, cohort studies of rural farmers and other residents can be conducted. The exposure data obtained by portable samplers can be combined with daily health data to analyze the health effects of agricultural air pollutants.

Author Contributions: Conceptualization, M.C. and P.G.; formal analysis, Y.C.; investigation, Y.C.; resources, D.N.; data curation, D.N.; writing—original draft preparation, P.G.; writing-review and editing, P.G.; funding acquisition, M.C. All authors have read and agreed to the published version of the manuscript.

Funding: This research was funded by the National Natural Science Foundation of China, grant number 21976094; and the National Key Research and Development Project, grant number 2018YFC0213802.

Conflicts of Interest: The authors declare no conflict of interest.

\section{References}

1. Jiaqiang, E.; Pham, M.; Zhao, D.; Deng, Y.; Le, D.; Zuo, W.; Zhu, H.; Liu, T.; Peng, Q.; Zhang, Z. Effect of different technologies on combustion and emissions of the diesel engine fueled with biodiesel: A review. Renew. Sustain. Energy Rev. 2017, 80, 620-647. [CrossRef]

2. Finkelman, R.B.; Tian, L. The health impacts of coal use in China. Int. Geol. Rev. 2017, 60, 579-589. [CrossRef]

3. Zhang, Y.-J.; Hao, J.-F.; Song, J. The $\mathrm{CO}_{2}$ emission efficiency, reduction potential and spatial clustering in China's industry: Evidence from the regional level. Appl. Energy 2016, 174, 213-223. [CrossRef]

4. Zhao, L.; Xu, Y.; Hou, H.; Shangguan, Y.; Li, F. Source identification and health risk assessment of metals in urban soils around the Tanggu chemical industrial district, Tianjin, China. Sci. Total Environ. 2014, 468-469, 654-662. [CrossRef]

5. Guarnieri, M.; Balmes, J.R. Outdoor air pollution and asthma. Lancet 2014, 383, 1581-1592. [CrossRef]

6. Wu, Y.; Zhang, S.; Hao, J.; Liu, H.; Wu, X.; Hu, J.; Walsh, M.P.; Wallington, T.J.; Zhang, K.M.; Stevanovic, S. On-road vehicle emissions and their control in China: A review and outlook. Sci. Total Environ. 2017, 574, 332-349. [CrossRef]

7. Reay, D.S.; Davidson, E.A.; Smith, K.A.; Smith, P.; Melillo, J.M.; Dentener, F.; Crutzen, P.J. Global agriculture and nitrous oxide emissions. Nat. Clim. Chang. 2012, 2, 410-416. [CrossRef]

8. Van Damme, M.; Clarisse, L.; Whitburn, S.; Hadji-Lazaro, J.; Hurtmans, D.; Clerbaux, C.; Coheur, P.F. Industrial and agricultural ammonia point sources exposed. Nature 2018, 564, 99-103. [CrossRef]

9. Guan, W.-J.; Zheng, X.-Y.; Chung, K.F.; Zhong, N.-S. Impact of air pollution on the burden of chronic respiratory diseases in China: Time for urgent action. Lancet 2016, 388, 1939-1951. [CrossRef]

10. Zhang, C.; Zeng, G.; Huang, D.; Lai, C.; Chen, M.; Cheng, M.; Tang, W.; Tang, L.; Dong, H.; Huang, B.; et al. Biochar for environmental management: Mitigating greenhouse gas emissions, contaminant treatment, and potential negative impacts. Chem. Eng. J. 2019, 373, 902-922. [CrossRef]

11. Mikulčić, H.; Klemeš, J.J.; Vujanović, M.; Urbaniec, K.; Duić, N. Reducing greenhouse gasses emissions by fostering the deployment of alternative raw materials and energy sources in the cleaner cement manufacturing process. J. Clean Prod. 2016, 136, 119-132. [CrossRef]

12. Ramzan, S.; Rasool, T.; Bhat, R.A.; Ahmad, P.; Ashraf, I.; Rashid, N.; Ul Shafiq, M.; Mir, I.A. Agricultural soils a trigger to nitrous oxide: A persuasive greenhouse gas and its management. Environ. Monit. Assess. 2020, 192, 436. [CrossRef] [PubMed]

13. Signor, D.; Cerri, C.E.P.; Conant, R. $\mathrm{N}_{2} \mathrm{O}$ emissions due to nitrogen fertilizer applications in two regions of sugarcane cultivation in Brazil. Environ. Res. Lett. 2013, 8. [CrossRef]

14. Wu, S.; Chen, J.; Li, C.; Kong, D.; Yu, K.; Liu, S.; Zou, J. Diel and seasonal nitrous oxide fluxes determined by floating chamber and gas transfer equation methods in agricultural irrigation watersheds in southeast China. Environ. Monit. Assess. 2018, 190, 122. [CrossRef] [PubMed]

15. Paulot, F.; Jacob, D.J.; Pinder, R.W.; Bash, J.O.; Travis, K.; Henze, D.K. Ammonia emissions in the United States, European Union, and China derived by high-resolution inversion of ammonium wet deposition data: Interpretation with a new agricultural emissions inventory (MASAGE_NH 3 ). J. Geophys. Res. Atmos. 2014, 119, 4343-4364. [CrossRef]

16. Backes, A.M.; Aulinger, A.; Bieser, J.; Matthias, V.; Quante, M. Ammonia emissions in Europe, part II: How ammonia emission abatement strategies affect secondary aerosols. Atmos. Environ. 2016, 126, 153-161. [CrossRef]

17. Pan, Y.; Tian, S.; Liu, D.; Fang, Y.; Zhu, X.; Gao, M.; Wentworth, G.R.; Michalski, G.; Huang, X.; Wang, Y. Source Apportionment of Aerosol Ammonium in an Ammonia-Rich Atmosphere: An Isotopic Study of Summer Clean and Hazy Days in Urban Beijing. J. Geophys. Res. Atmos. 2018, 123, 5681-5689. [CrossRef]

18. Wu, C.; Wang, G.; Li, J.; Li, J.; Cao, C.; Ge, S.; Xie, Y.; Chen, J.; Liu, S.; Du, W.; et al. Non-agricultural sources dominate the atmospheric $\mathrm{NH}_{3}$ in $\mathrm{Xi}^{\prime}$ an, a megacity in the semi-arid region of China. Sci. Total Environ. 2020, 722, 137756. [CrossRef]

19. Lamarque, J.F.; Bond, T.C.; Eyring, V.; Granier, C.; Heil, A.; Klimont, Z.; Lee, D.; Liousse, C.; Mieville, A.; Owen, B.; et al. Historical (1850-2000) gridded anthropogenic and biomass burning emissions of reactive gases and aerosols: Methodology and application. Atmos. Chem. Phys. 2010, 10, 7017-7039. [CrossRef] 
20. Lamarque, J.-F.; Kyle, G.P.; Meinshausen, M.; Riahi, K.; Smith, S.J.; van Vuuren, D.P.; Conley, A.J.; Vitt, F. Global and regional evolution of short-lived radiatively-active gases and aerosols in the Representative Concentration Pathways. Clim. Chang. 2011, 109, 191-212. [CrossRef]

21. Bauer, S.E.; Tsigaridis, K.; Miller, R. Significant atmospheric aerosol pollution caused by world food cultivation. Geophys. Res. Lett. 2016, 43, 5394-5400. [CrossRef]

22. Lelieveld, J.; Evans, J.S.; Fnais, M.; Giannadaki, D.; Pozzer, A. The contribution of outdoor air pollution sources to premature mortality on a global scale. Nature 2015, 525, 367-371. [CrossRef] [PubMed]

23. Shen, L.; Jacob, D.J.; Zhu, L.; Zhang, Q.; Zheng, B.; Sulprizio, M.P.; Li, K.; De Smedt, I.; González Abad, G.; Cao, H.; et al. The 2005-2016 Trends of Formaldehyde Columns Over China Observed by Satellites: Increasing Anthropogenic Emissions of Volatile Organic Compounds and Decreasing Agricultural Fire Emissions. Geophys. Res. Lett. 2019, 46, 4468-4475. [CrossRef]

24. Erisman, J.W.; Bleeker, A.; Hensen, A.; Vermeulen, A. Agricultural air quality in Europe and the future perspectives. Atmos. Environ. 2008, 42, 3209-3217. [CrossRef]

25. Reis, S.; Pinder, R.W.; Zhang, M.; Lijie, G.; Sutton, M.A. Reactive nitrogen in atmospheric emission inventories. Atmos. Chem. Phys. 2009, 9, 7657-7677. [CrossRef]

26. Pinder, R.W.; Strader, R.; Davidson, C.I.; Adams, P.J. A temporally and spatially resolved ammonia emission inventory for dairy cows in the United States. Atmos. Environ. 2004, 38, 3747-3756. [CrossRef]

27. Zhou, Z.; Tan, Q.; Deng, Y.; Wu, K.; Yang, X.; Zhou, X. Emission inventory of anthropogenic air pollutant sources and characteristics of VOCs species in Sichuan Province, China. J. Atmos. Chem. 2019, 76, 21-58. [CrossRef]

28. Stevenazzi, S.; Camera, C.A.S.; Masetti, M.; Azzoni, R.S.; Ferrari, E.S.; Tiepolo, M. Atmospheric Nitrogen Depositions in a Highly Human-Impacted Area. Water Air Soil Pollut. 2020, 231. [CrossRef]

29. Gu, B.; Ge, Y.; Ren, Y.; Xu, B.; Luo, W.; Jiang, H.; Gu, B.; Chang, J. Atmospheric reactive nitrogen in China: Sources, recent trends, and damage costs. Environ. Sci. Technol. 2012, 46, 9420-9427. [CrossRef]

30. Chen, S.; Cheng, M.; Guo, Z.; Xu, W.; Du, X.; Li, Y. Enhanced atmospheric ammonia $\left(\mathrm{NH}_{3}\right)$ pollution in China from 2008 to 2016 Evidence from a combination of observations and emissions. Environ. Pollut. 2020, 263, 114421. [CrossRef]

31. Lesschen, J.P.; van den Berg, M.; Westhoek, H.J.; Witzke, H.P.; Oenema, O. Greenhouse gas emission profiles of European livestock sectors. Anim. Feed Sci. Technol. 2011, 166-167, 16-28. [CrossRef]

32. Chen, Z.; An, C.; Fang, H.; Zhang, Y.; Zhou, Z.; Zhou, Y.; Zhao, S. Assessment of regional greenhouse gas emission from beef cattle production: A case study of Saskatchewan in Canada. J. Environ. Manag. 2020, 264, 110443. [CrossRef] [PubMed]

33. Kammer, J.; Decuq, C.; Baisnee, D.; Ciuraru, R.; Lafouge, F.; Buysse, P.; Bsaibes, S.; Henderson, B.; Cristescu, S.M.; Benabdallah, R.; et al. Characterization of particulate and gaseous pollutants from a French dairy and sheep farm. Sci. Total Environ. 2020, 712, 135598. [CrossRef]

34. Syed, J.H.; Malik, R.N.; Liu, D.; Xu, Y.; Wang, Y.; Li, J.; Zhang, G.; Jones, K.C. Organochlorine pesticides in air and soil and estimated air-soil exchange in Punjab, Pakistan. Sci. Total Environ. 2013, 444, 491-497. [CrossRef]

35. Nasir, J.; Wang, X.; Xu, B.; Wang, C.; Joswiak, D.R.; Rehman, S.; Lodhi, A.; Shafiq, S.; Jilani, R. Selected organochlorine pesticides and polychlorinated biphenyls in urban atmosphere of Pakistan: Concentration, spatial variation and sources. Environ. Sci. Technol. 2014, 48, 2610-2618. [CrossRef]

36. Wang, J.; Li, L.; Liu, J.; Ti, B. Distribution mode and environmental risk of POP pesticides such as endosulfan under the agricultural practice of straw incorporating. Environ. Pollut. 2017, 220, 1394-1399. [CrossRef]

37. Pegoraro, C.N.; Wannaz, E.D. Occurrence of persistent organic pollutants in air at different sites in the province of Cordoba, Argentina. Environ. Sci. Pollut. Res. Int. 2019, 26, 18379-18391. [CrossRef]

38. Rajput, P.; Sarin, M.M.; Sharma, D.; Singh, D. Atmospheric polycyclic aromatic hydrocarbons and isomer ratios as tracers of biomass burning emissions in Northern India. Environ. Sci. Pollut. Res. Int. 2014, 21, 5724-5729. [CrossRef] [PubMed]

39. Pongpiachan, S.; Hattayanone, M.; Cao, J. Effect of agricultural waste burning season on $\mathrm{PM}_{2.5}$-bound polycyclic aromatic hydrocarbon (PAH) levels in Northern Thailand. Atmos. Pollut. Res. 2017, 8, 1069-1080. [CrossRef]

40. Junpen, A.; Pansuk, J.; Kamnoet, O.; Cheewaphongphan, P.; Garivait, S. Emission of Air Pollutants from Rice Residue Open Burning in Thailand, 2018. Atmosphere 2018, 9, 449. [CrossRef]

41. Wu, J.; Kong, S.; Wu, F.; Cheng, Y.; Zheng, S.; Qin, S.; Liu, X.; Yan, Q.; Zheng, H.; Zheng, M.; et al. The moving of high emission for biomass burning in China: View from multi-year emission estimation and human-driven forces. Environ. Int. 2020, $142,105812$. [CrossRef] [PubMed]

42. Lang, J.; Tian, J.; Zhou, Y.; Li, K.; Chen, D.; Huang, Q.; Xing, X.; Zhang, Y.; Cheng, S. A high temporal-spatial resolution air pollutant emission inventory for agricultural machinery in China. J. Clean Prod. 2018, 183, 1110-1121. [CrossRef]

43. Hou, X.; Tian, J.; Song, C.; Wang, J.; Zhao, J.; Zhang, X. Emission inventory research of typical agricultural machinery in Beijing, China. Atmos. Environ. 2019, 216. [CrossRef]

44. Guo, X.; Wu, H.; Chen, D.; Ye, Z.; Shen, Y.; Liu, J.; Cheng, S. Estimation and prediction of pollutant emissions from agricultural and construction diesel machinery in the Beijing-Tianjin-Hebei (BTH) region, China. Environ. Pollut. 2020, 260, 113973. [CrossRef] [PubMed]

45. Zhang, J.; Liu, L.; Zhao, Y.; Li, H.; Lian, Y.; Zhang, Z.; Huang, C.; Du, X. Development of a high-resolution emission inventory of agricultural machinery with a novel methodology: A case study for Yangtze River Delta region. Environ. Pollut. 2020, $266,115075$. [CrossRef] [PubMed] 
46. Hofmann, H. Spatiotemporal distribution patterns of dissolved methane in lakes: How accurate are the current estimations of the diffusive flux path? Geophys. Res. Lett. 2013, 40, 2779-2784. [CrossRef]

47. Beaulieu, J.J.; Smolenski, R.L.; Nietch, C.T.; Townsend-Small, A.; Elovitz, M.S. High methane emissions from a midlatitude reservoir draining an agricultural watershed. Environ. Sci. Technol. 2014, 48, 11100-11108. [CrossRef] [PubMed]

48. Cao, W.; Liu, S.; Qu, Z.; Song, H.; Qin, W.; Guo, J.; Chen, Q.; Lin, S.; Wang, J. Contribution and Driving Mechanism of N $2 \mathrm{O}$ Emission Bursts in a Chinese Vegetable Greenhouse after Manure Application and Irrigation. Sustainability 2019, $11,1624$. [CrossRef]

49. Bhatia, A.; Jain, N.; Pathak, H. Methane and nitrous oxide emissions from Indian rice paddies, agricultural soils and crop residue burning. Greenh. Gases 2013, 3, 196-211. [CrossRef]

50. Hayashi, K.; Yan, X. Airborne nitrogen load in Japanese and Chinese agroecosystems. Soil Sci. Plant Nutr. 2010, 56, 2-18. [CrossRef]

51. Sintermann, J.; Schallhart, S.; Kajos, M.; Jocher, M.; Bracher, A.; Münger, A.; Johnson, D.; Neftel, A.; Ruuskanen, T. Trimethylamine emissions in animal husbandry. Biogeosciences 2014, 11, 5073-5085. [CrossRef]

52. Vazquez-Carrillo, M.F.; Montelongo-Perez, H.D.; Gonzalez-Ronquillo, M.; Castillo-Gallegos, E.; Castelan-Ortega, O.A. Effects of Three Herbs on Methane Emissions from Beef Cattle. Animals 2020, 10, 1671. [CrossRef]

53. Pozo, K.; Harner, T.; Lee, S.C.; Sinha, R.K.; Sengupta, B.; Loewen, M.; Geethalakshmi, V.; Kannan, K.; Volpi, V. Assessing seasonal and spatial trends of persistent organic pollutants (POPs) in Indian agricultural regions using PUF disk passive air samplers. Environ. Pollut. 2011, 159, 646-653. [CrossRef] [PubMed]

54. Cortes, S.; Pozo, K.; Llanos, Y.; Martinez, N.; Foerster, C.; Leiva, C.; Ustáriz, J.; Přibylová, P.; Klánová, J.; Jorquera, H. First measurement of human exposure to current use pesticides (CUPs) in the atmosphere of central Chile: The case study of Mauco cohort. Atmos. Pollut. Res. 2020, 11, 776-784. [CrossRef]

55. Wang, X.; Kennedy, K.; Powell, J.; Keywood, M.; Gillett, R.; Thai, P.; Bridgen, P.; Broomhall, S.; Paxman, C.; Wania, F.; et al. Spatial distribution of selected persistent organic pollutants (POPs) in Australia's atmosphere. Environ. Sci. Process Impacts 2015, 17, 525-532. [CrossRef] [PubMed]

56. Wang, X.; Gong, P.; Wang, C.; Wang, X.; Pokhrel, B.; Dotel, J. Spatial distribution patterns and human exposure risks of polycyclic aromatic hydrocarbons, organochlorine pesticides and polychlorinated biphenyls in Nepal using tree bark as a passive air sampler. Environ. Res. 2020, 186, 109510. [CrossRef] [PubMed]

57. Qu, C.; Albanese, S.; Lima, A.; Hope, D.; Pond, P.; Fortelli, A.; Romano, N.; Cerino, P.; Pizzolante, A.; De Vivo, B. The occurrence of OCPs, PCBs, and PAHs in the soil, air, and bulk deposition of the Naples metropolitan area, southern Italy: Implications for sources and environmental processes. Environ. Int. 2019, 124, 89-97. [CrossRef]

58. Santiago-De La Rosa, N.; Gonzalez-Cardoso, G.; Figueroa-Lara, J.J.; Gutierrez-Arzaluz, M.; Octaviano-Villasana, C.; RamirezHernandez, I.F.; Mugica-Alvarez, V. Emission factors of atmospheric and climatic pollutants from crop residues burning. J. Air Waste Manag. Assoc. 2018, 68, 849-865. [CrossRef]

59. Punsompong, P.; Chantara, S. Identification of potential sources of $\mathrm{PM}_{10}$ pollution from biomass burning in northern Thailand using statistical analysis of trajectories. Atmos. Pollut. Res. 2018, 9, 1038-1051. [CrossRef]

60. Wang, X.; Chen, Y.; Tian, C.; Huang, G.; Fang, Y.; Zhang, F.; Zong, Z.; Li, J.; Zhang, G. Impact of agricultural waste burning in the Shandong Peninsula on carbonaceous aerosols in the Bohai Rim, China. Sci. Total Environ. 2014, 481, 311-316. [CrossRef]

61. Lammel, G.; Heil, A.; Stemmler, I.; Dvorska, A.; Klanova, J. On the contribution of biomass burning to POPs (PAHs and PCDDs) in air in Africa. Environ. Sci. Technol. 2013, 47, 11616-11624. [CrossRef] [PubMed]

62. Chang, D.; Song, Y. Estimates of biomass burning emissions in tropical Asia based on satellite-derived data. Atmos. Chem. Phys. 2010, 10, 2335-2351. [CrossRef]

63. Qin, Y.; Xie, S.D. Historical estimation of carbonaceous aerosol emissions from biomass open burning in China for the period 1990-2005. Environ. Pollut. 2011, 159, 3316-3323. [CrossRef] [PubMed]

64. Qin, Y.; Xie, S.D. Spatial and temporal variation of anthropogenic black carbon emissions in China for the period 1980-2009. Atmos. Chem. Phys. 2012, 12, 4825-4841. [CrossRef]

65. Jain, N.; Bhatia, A.; Pathak, H. Emission of Air Pollutants from Crop Residue Burning in India. Aerosol Air Qual. Res. 2014, 14, 422-430. [CrossRef]

66. Wang, F.; Li, Z.; Zhang, K.; Di, B.; Hu, B. An overview of non-road equipment emissions in China. Atmos. Environ. 2016, 132, 283-289. [CrossRef]

67. Adhikari, S.; Mahapatra, P.; Sapkota, V.; Puppala, S. Characterizing Emissions from Agricultural Diesel Pumps in the Terai Region of Nepal. Atmosphere 2019, 10, 56. [CrossRef]

68. Chen, X.; Jeong, S.-J. Irrigation enhances local warming with greater nocturnal warming effects than daytime cooling effects. Environ. Res. Lett. 2018, 13. [CrossRef]

69. Behera, S.N.; Sharma, M.; Aneja, V.P.; Balasubramanian, R. Ammonia in the atmosphere: A review on emission sources, atmospheric chemistry and deposition on terrestrial bodies. Environ. Sci. Pollut. Res. Int. 2013, 20, 8092-8131. [CrossRef]

70. Ramsay, R.; Di Marco, C.F.; Heal, M.R.; Twigg, M.M.; Cowan, N.; Jones, M.R.; Leeson, S.R.; Bloss, W.J.; Kramer, L.J.; Crilley, L.; et al. Surface-atmosphere exchange of inorganic water-soluble gases and associated ions in bulk aerosol above agricultural grassland pre- and postfertilisation. Atmos. Chem. Phys. 2018, 18, 16953-16978. [CrossRef] 
71. Ramanantenasoa, M.M.J.; Génermont, S.; Gilliot, J.-M.; Bedos, C.; Makowski, D. Meta-modeling methods for estimating ammonia volatilization from nitrogen fertilizer and manure applications. J. Environ. Manag. 2019, 236, 195-205. [CrossRef]

72. Ye, Z.; Guo, X.; Cheng, L.; Cheng, S.; Chen, D.; Wang, W.; Liu, B. Reducing $\mathrm{PM}_{2.5}$ and secondary inorganic aerosols by agricultural ammonia emission mitigation within the Beijing-Tianjin-Hebei region, China. Atmos. Environ. 2019, 219. [CrossRef]

73. Meiirkhanuly, Z.; Koziel, J.A.; Chen, B.; Białowiec, A.; Lee, M.; Wi, J.; Banik, C.; Brown, R.C.; Bakshi, S. Mitigation of Gaseous Emissions from Swine Manure with the Surficial Application of Biochars. Atmosphere 2020, 11, 1179. [CrossRef]

74. Davis, S.C.; Parton, W.J.; Grosso, S.J.D.; Keough, C.; Marx, E.; Adler, P.R.; DeLucia, E.H. Impact of second-generation biofuel agriculture on greenhouse-gas emissions in the corn-growing regions of the US. Front. Ecol. Environ. 2011, 10, 69-74. [CrossRef]

75. Aguirre-Villegas, H.A.; Larson, R.A.; Sharara, M.A. Anaerobic digestion, solid-liquid separation, and drying of dairy manure: Measuring constituents and modeling emission. Sci. Total Environ. 2019, 696. [CrossRef]

76. Philippe, V.; Neveen, A.; Marwa, A.; Ahmad Basel, A.-Y. Occurrence of pesticide residues in fruits and vegetables for the Eastern Mediterranean Region and potential impact on public health. Food Control 2021, 119. [CrossRef]

77. Zapevalov, M.A.; Samsonov, D.P.; Kochetkov, A.I.; Pasynkova, E.M.; Bogacheva, E.G. Global Atmospheric Transport of Persistent Organic Pollutants to the Russian Arctic. Russ. Meteorol. Hydrol. 2020, 45, 658-668. [CrossRef]

78. Kosikowska, M.; Biziuk, M. Review of the determination of pesticide residues in ambient air. TrAC Trends Anal. Chem. 2010, 29, 1064-1072. [CrossRef]

79. Bartrons, M.; Catalan, J.; Penuelas, J. Spatial and Temporal Trends of Organic Pollutants in Vegetation from Remote and Rural Areas. Sci. Rep. 2016, 6, 25446. [CrossRef]

80. Liao, Y.; Wu, W.L.; Meng, F.Q.; Smith, P.; Lal, R. Increase in soil organic carbon by agricultural intensification in northern China. Biogeosciences 2015, 12, 1403-1413. [CrossRef]

81. Ishii, K.; Furuichi, T. Influence of moisture content, particle size and forming temperature on productivity and quality of rice straw pellets. Waste Manag. 2014, 34, 2621-2626. [CrossRef]

82. Tiyapairat, Y.; Sajor, E.E. State simplification, heterogeneous causes of vegetation fires and implications on local haze management: Case study in Thailand. Environ. Dev. Sustain. 2012, 14, 1047-1064. [CrossRef]

83. Beuchelt, T.D.; Camacho Villa, C.T.; Göhring, L.; Hernández Rodríguez, V.M.; Hellin, J.; Sonder, K.; Erenstein, O. Social and income trade-offs of conservation agriculture practices on crop residue use in Mexico's central highlands. Agric. Syst. 2015, 134, 61-75. [CrossRef]

84. Sun, J.; Peng, H.; Chen, J.; Wang, X.; Wei, M.; Li, W.; Yang, L.; Zhang, Q.; Wang, W.; Mellouki, A. An estimation of CO 2 emission via agricultural crop residue open field burning in China from 1996 to 2013. J. Clean Prod. 2016, 112, 2625-2631. [CrossRef]

85. Arunrat, N.; Pumijumnong, N.; Sereenonchai, S. Air-Pollutant Emissions from Agricultural Burning in Mae Chaem Basin, Chiang Mai Province, Thailand. Atmosphere 2018, 9, 145. [CrossRef]

86. Zhang, G.; Li, J.; Li, X.D.; Xu, Y.; Guo, L.L.; Tang, J.H.; Lee, C.S.; Liu, X.; Chen, Y.J. Impact of anthropogenic emissions and open biomass burning on regional carbonaceous aerosols in South China. Environ. Pollut. 2010, 158, 3392-3400. [CrossRef] [PubMed]

87. Li, J.; Li, Y.; Bo, Y.; Xie, S. High-resolution historical emission inventories of crop residue burning in fields in China for the period 1990-2013. Atmos. Environ. 2016, 138, 152-161. [CrossRef]

88. Cao, G.; Zhang, X.; Gong, S.; An, X.; Wang, Y. Emission inventories of primary particles and pollutant gases for China. Chin. Sci. Bull. 2011, 56, 781-788. [CrossRef]

89. Zheng, B.; Tong, D.; Li, M.; Liu, F.; Hong, C.; Geng, G.; Li, H.; Li, X.; Peng, L.; Qi, J.; et al. Trends in China's anthropogenic emissions since 2010 as the consequence of clean air actions. Atmos. Chem. Phys. 2018, 18, 14095-14111. [CrossRef]

90. Zhao, H.; Tong, D.Q.; Gao, C.; Wang, G. Effect of dramatic land use change on gaseous pollutant emissions from biomass burning in Northeastern China. Atmos. Res. 2015, 153, 429-436. [CrossRef]

91. Li, X.; Zhang, C.; Liu, P.; Liu, J.; Zhang, Y.; Liu, C.; Mu, Y. Significant influence of the intensive agricultural activities on atmospheric $\mathrm{PM}_{2.5}$ during autumn harvest seasons in a rural area of the North China Plain. Atmos. Environ. 2020, 241. [CrossRef]

92. Bacenetti, J.; Lovarelli, D.; Facchinetti, D.; Pessina, D. An environmental comparison of techniques to reduce pollutants emissions related to agricultural tractors. Biosyst. Eng. 2018, 171, 30-40. [CrossRef]

93. Yang, S.; Peng, S.; Xu, J.; Luo, Y.; Li, D. Methane and nitrous oxide emissions from paddy field as affected by water-saving irrigation. Phys. Chem. Earth 2012, 53-54, 30-37. [CrossRef]

94. Wu, J.; Guo, W.; Feng, J.; Li, L.; Yang, H.; Wang, X.; Bian, X. Greenhouse gas emissions from cotton field under different irrigation methods and fertilization regimes in arid northwestern China. Sci. World J. 2014, 2014, 407832. [CrossRef] [PubMed]

95. Cardozo, N.P.; Bordonal, R.d.O.; La Scala, N. Greenhouse gas emission estimate in sugarcane irrigation in Brazil: Is it possible to reduce it, and still increase crop yield? J. Clean Prod. 2016, 112, 3988-3997. [CrossRef]

96. Murray, R.H.; Erler, D.V.; Eyre, B.D. Nitrous oxide fluxes in estuarine environments: Response to global change. Glob. Chang. Biol. 2015, 21, 3219-3245. [CrossRef]

97. Niu, L.; Xu, C.; Yao, Y.; Liu, K.; Yang, F.; Tang, M.; Liu, W. Status, influences and risk assessment of hexachlorocyclohexanes in agricultural soils across china. Environ. Sci. Technol. 2013, 47, 12140-12147. [CrossRef] [PubMed]

98. Munoz-Quezada, M.T.; Lucero, B.; Iglesias, V.; Levy, K.; Munoz, M.P.; Achu, E.; Cornejo, C.; Concha, C.; Brito, A.M.; Villalobos, M. Exposure to organophosphate (OP) pesticides and health conditions in agricultural and non-agricultural workers from Maule, Chile. Int. J. Environ. Health Res. 2017, 27, 82-93. [CrossRef] [PubMed] 
99. Niu, X.; Chuang, H.-C.; Wang, X.; Ho, S.S.H.; Li, L.; Qu, L.; Chow, J.C.; Watson, J.G.; Sun, J.; Lee, S.; et al. Cytotoxicity of PM 2.5 vehicular emissions in the Shing Mun Tunnel, Hong Kong. Environ. Pollut. 2020, 263. [CrossRef]

100. Tong, X.; Chen, X.-C.; Chuang, H.-C.; Cao, J.-J.; Ho, S.S.H.; Lui, K.-H.; Ho, K.F. Characteristics and cytotoxicity of indoor fine particulate matter $\left(\mathrm{PM}_{2.5}\right)$ and $\mathrm{PM}_{2.5}$-bound polycyclic aromatic hydrocarbons (PAHs) in Hong Kong. Air Qual. Atmos. Health 2019, 12, 1459-1468. [CrossRef]

101. Melki, P.N.; Ledoux, F.; Aouad, S.; Billet, S.; El Khoury, B.; Landkocz, Y.; Abdel-Massih, R.M.; Courcot, D. Physicochemical characteristics, mutagenicity and genotoxicity of airborne particles under industrial and rural influences in Northern Lebanon. Environ. Sci. Pollut. Res. 2017, 24, 18782-18797. [CrossRef]

102. Pardo, M.; Xu, F.; Qiu, X.; Zhu, T.; Rudich, Y. Seasonal variations in fine particle composition from Beijing prompt oxidative stress response in mouse lung and liver. Sci. Total Environ. 2018, 626, 147-155. [CrossRef]

103. Song, Y.; Li, R.; Zhang, Y.; Wei, J.; Chen, W.; Chung, C.K.A.; Cai, Z. Mass spectrometry-based metabolomics reveals the mechanism of ambient fine particulate matter and its components on energy metabolic reprogramming in BEAS-2B cells. Sci. Total Environ. 2019, 651, 3139-3150. [CrossRef] [PubMed]

104. Chen, Q.; Luo, X.-S.; Chen, Y.; Zhao, Z.; Hong, Y.; Pang, Y.; Huang, W.; Wang, Y.; Jin, L. Seasonally varied cytotoxicity of organic components in $\mathrm{PM}_{2.5}$ from urban and industrial areas of a Chinese megacity. Chemosphere 2019, 230, 424-431. [CrossRef]

105. Lin, H.; Tao, J.; Du, Y.; Liu, T.; Qian, Z.; Tian, L.; Di, Q.; Zeng, W.; Xiao, J.; Guo, L.; et al. Differentiating the effects of characteristics of PM pollution on mortality from ischemic and hemorrhagic strokes. Int. J. Hyg. Environ. Health 2016, 219, 204-211. [CrossRef] [PubMed]

106. Qiao, P.; Zhao, Y.; Cai, J.; van Donkelaar, A.; Martin, R.; Ying, H.; Kan, H. Twin growth discordance in association with maternal exposure to fine particulate matter and its chemical constituents during late pregnancy. Environ. Int. 2019, 133. [CrossRef]

107. Wong, C.M.; Lai, H.K.; Tsang, H.; Thach, T.Q.; Thomas, G.N.; Lam, K.B.; Chan, K.P.; Yang, L.; Lau, A.K.; Ayres, J.G.; et al. SatelliteBased Estimates of Long-Term Exposure to Fine Particles and Association with Mortality in Elderly Hong Kong Residents. Environ. Health Perspect. 2015, 123, 1167-1172. [CrossRef]

108. Compton, J.E.; Harrison, J.A.; Dennis, R.L.; Greaver, T.L.; Hill, B.H.; Jordan, S.J.; Walker, H.; Campbell, H.V. Ecosystem services altered by human changes in the nitrogen cycle: A new perspective for US decision making. Ecol. Lett. 2011, 14, 804-815. [CrossRef] [PubMed]

109. Bourne, M.; Childs, J.; Philippidis, G.; Feijoo, M. Controlling greenhouse gas emissions in Spain: What are the costs for agricultural sectors? Span. J. Agric. Res. 2012, 10. [CrossRef]

110. Van Kessel, C.; Venterea, R.; Six, J.; Adviento-Borbe, M.A.; Linquist, B.; van Groenigen, K.J. Climate, duration, and N placement determine $\mathrm{N}_{2} \mathrm{O}$ emissions in reduced tillage systems: A meta-analysis. Glob. Chang. Biol. 2013, 19, 33-44. [CrossRef] [PubMed]

111. Xu, Z.; Liu, M.; Zhang, M.; Song, Y.; Wang, S.; Zhang, L.; Xu, T.; Wang, T.; Yan, C.; Zhou, T.; et al. High efficiency of livestock ammonia emission controls in alleviating particulate nitrate during a severe winter haze episode in northern China. Atmos. Chem. Phys. 2019, 19, 5605-5613. [CrossRef] 